\title{
Plasma Biochemistry values in wild female hawksbill turtle (Eretmochelys imbricata) during nesting in Mexican coast
}

\section{Valores de bioquímica plasmática em tartaruga de pente (Eretmochelys imbricata) durante a época de desova na costa mexicana}

\author{
Patricia Ishisaki SALVARANI'1 Jaime Rendón von OSTEN²; Fernando MORGADO \\ ${ }^{1}$ University of Aveiro, Centre for Environmental and Marine Studies, Department of Biology, Aveiro - Portugal \\ ${ }^{2}$ Universidad Autónoma de Campeche, Instituto Epomex, Campeche - Mexico
}

\begin{abstract}
To obtain plasma biochemistry values, blood was collected for 47 nesting females of apparently healthy Eretmochelys imbricata sea turtles using sodium heparin as an anticoagulant. Blood samples were collected in April-Jun for two years (nesting season). Hematologic characteristics, including packed cell volume, white blood cell counts, red blood cell count and hemoglobin level; and plasma chemistry values, including creatinine, blood urea nitrogen, uric acid, triglyceride, total cholesterol, and glucose were measured. The data generated from this study may be useful for clinical assessment of health and disease of wild hawksbill sea turtles on nearshore habitats in the Gulf of Mexico, thus contributing to a conservation of this species.
\end{abstract}

Keywords: Eretmochelys imbricata. Hematology. Plasma chemistry. Conservation.

\section{Resumo}

Para obter valores da bioquímica plasmática, foram coletadas amostras de sangue durante a desova de 47 tartarugas marinhas fêmeas aparentemente saudáveis da espécie Eretmochelys imbricata, utilizando heparina sódica como anticoagulante. Amostras de sangue foram coletadas durante dois anos entre os meses de abril e junho (época de nidificação). Mediu-se os parâmetros hematológicos (incluindo hematócrito, contagem de glóbulos brancos e vermelhos e nível de hemoglobina) e os valores da bioquímica plasmática (incluindo creatinina, ureia, ácido úrico, triglicérides, colesterol total e glicose). Os dados gerados a partir deste estudo podem ser úteis para a avaliação clínica de saúde e de doença em tartarugas-de-pente em habitats próximos ao litoral no Golfo do México, contribuindo para a conservação dessa espécie.

Palavras-chave: Eretmochelys imbricata. Hematologia. Bioquímica Plasmática. Conservação.

Correspondence to:

Patricia Ishisaki Salvarani

University of Aveiro, Centre for Environmental and Marine

Studies, Department of Biology

Campus Universitário de Santiago

CP 3810-193, Avieiro, Portugal

e-mail: patysalvarani@hotmail.com

Received: 25/7/2017

Approved: 11/12/2017

\section{Introduction}

Marine turtles face an increasing number of threats that are both natural and human-caused, which create obstacles to the turtles' survival and threaten to drive them to extinction (IUCN, 1995; LUTCAVAGE et al., 1997). Thus, a complete evaluation of the host immune response and the susceptibility of these endangered animals is required (AGUIRRE; BALAZS, 2000; SWIMMWER, 2000; ROUSSELET et al., 2013).
Due to several factors, such as age, size, sex, season, health, habitat and diet, it is difficult to make a comparative analysis of blood reference values between individual sea turtles, which may affect hematological parameters (WOOD; EBANKS, 1984; AGUIRRE et al., 1995). Since the changes in blood chemistry can be related to their physiological state and can still be used for the identification of pathological conditions, it is important to know the normal blood standard for any animal (LUTZ; DUNBARCOOPER, 1987).

Hematological analysis has been used worldwide with excellent results as an important technique in the investigation of diseases in reptiles, showing physiological changes between free-living animals and monitoring the health of captive animals (BOLTEN; BJORDAL, 1992; CHRISTOPHER et al., 1999; PIRES et al., 2009). According to Bolten and Bjordal (1992), although some studies are published on the hematological values of sea 
turtles, due to the methods of sampling, manipulation, processing and biochemical analysis, which vary widely between these works, it is difficult to use this information in comparative studies.

The hawksbill turtles, E. imbricata is listed as "critically endangered" in the IUCN Red List of Threatened Species (2016). Physical examinations, hematology, and plasma biochemistry reference ranges of biochemical parameters are considered important for assessing and monitoring the health status of sea turtles and creating suitable environmental indicators to improve the effectiveness of conservation strategies. The objective of this study was to produce working reference intervals for hematologic and plasma biochemical parameters of nesting hawksbill sea turtles along the Mexican coast (Punta Xen).

\section{Materials and Methods}

\section{Study area}

The studded hawksbill sea turtles (E. imbricata) were collected in Punta Xen Turtle camp, Campeche, México, a nesting area located in southeastern Mexico in the Yucatan Peninsula. The samples were collected in sea turtle camp Grupo Ecologista Quelonios A.C. of Punta Xen (19¹2’39” N, 9052’09.7” W). The study area, Punta Xen turtle camp, Campeche, México, is about 700 hectares of land located in a natural setting, mixed beach, sun, forest, mangroves and incalculable wealth of flora and fauna. A record of 289 hawksbill nests and 17,000,680 eggs of hawksbill (E. imbricata) and green turtle (C. mydas) has been recorded to date. In 2012, a total of 531 nests were protected and 48,000 hatchlings were released. However, in 2013, the amount of both nearly doubled, which means that more turtles are coming to spawn on the Campeche coast (ESCANERO et al., 1990; GUZMÁN; GARCÍA, 2010; MÉXICO, 2013).

\section{Blood sampling}

During the reproductive season of 2014 and 2015, blood samples were collected from 47 female hawksbill sea turtles. The license (SGPA/DGVS/03974/14) to collect the blood samples was provided by the Secretaria de Medio Ambiente y Recursos Naturales (Semarnat). Blood was drawn from the cervical vein sinus (OWENS; RUIZ,1980), since the turtle had just laid the eggs and was covering the nest. For each female, a total of $5 \mathrm{~mL}$ of blood was collected with a disposable syringe and collection tubes containing lithium heparin to prevent coagulation.

The samples were centrifuged at $4000 \mathrm{~g}$ for $10 \mathrm{~min}$ to obtain plasma which was stored at $-20^{\circ} \mathrm{C}$ until assay. The biological material collected was sent to and processed in the Central Laboratory of Animal Pathology of Campeche (Lacepac), Campeche, México. Plasma biochemistry determinations included cholesterol, glucose, triglycerides, urea, creatinine, and uric acid. For the statistical analysis (mean, standard deviation, minimum, and maximum), the $\mathrm{R}$ version 3.2.3 was used (THE R FOUNDATION, 2015). The statistical significance level was set at $\mathrm{p}<0.05$. The distribution of all parameters was tested for normality using a Shapiro-Wilk test. Correlations between Curved carapace length data and the biochemical parameters value of this study were evaluated using Pearson's chisquared test.

\section{Results}

\section{Physical examinations and morphometric}

Forty-seven animals were measured, ranging from 75.5 to $100.0 \mathrm{~cm}(89.20 \pm 6.38)$ of curvilinear carapace length. Thus, all animals were considered adults. Curved carapace length (CCL) and curved carapace width (CCW) was measured with a flexible tape measure (BOLTEN, 1999). No fibropapillomas were observed on any of the 47 turtles and all appeared in good body weight with adequate energy levels based on nesting behavior.

\section{Hematology and plasma biochemistry}

Range, mean, and standard deviation (Mean \pm SD) of biometric data and biochemical parameters of female foraging and nesting turtles are shown in tables 1 and 2 . Results of hematologic tests are provided in Table 1, the mean PCV was 0.80 with a range of $0.20 \pm 2.50$, the means WBC count was 215.50 with a range of $101.20 \pm 250.70$. Plasma biochemistry data are provided in Table 2, with values reported for blood collected in lithium heparin. Most of the biochemical parameters have significant correlation with biometric factors $(\mathrm{p}<0.05)$ with CCL. Urea $(p$-value $=0.494)$, Creatinine $(p$-value $=0.4227)$, Glucose ( $\mathrm{p}$-value $=0.4554)$, Cholesterol $(\mathrm{p}$-value $=0.08054)$, Uric acid $(\mathrm{p}$-value $=0.9309)$ and Triglyceride $(\mathrm{p}$-value $=0.4908)$.

Difference in the values verified in the literature is due to several factors such as the feeding variability and the capture stress, according to Bolten and Bjorndal (1992). 
Table 1 - Hematological values (mean \pm SD) and range in foraging hawksbill turtles nesting on the Mexican coast - Campeche $2014 / 2015$

\begin{tabular}{cccc}
\hline Parameter & N & Mean \pm SD & Range \\
\hline $\mathrm{WBC}-\times 10^{3} / \mu \mathrm{L}$ & 30 & $215,50 \pm 37,03$ & $101,20 \pm 250,70$ \\
$\mathrm{Hb}-\mathrm{g} / \mathrm{dL}$ & 30 & $10,76 \pm 1,48$ & $6,70 \pm 13,20$ \\
$\mathrm{PLT}-\times 10^{3} / \mu \mathrm{L}$ & 28 & $14,32 \pm 13,47$ & $2,00 \pm 59,00$ \\
$\mathrm{PCV}-\%$ & 27 & $0,80 \pm 0,77$ & $0,20 \pm 2,50$ \\
$\mathrm{RBC}-\mathrm{x} 10^{3} / \mu \mathrm{L}$ & 22 & $0,03 \pm 0,02$ & $0,02 \pm 0,11$ \\
\hline
\end{tabular}

$\mathrm{PCV}=$ packed cell volume; $\mathrm{WBC}=$ white blood cell count; $\mathrm{Hb}=$ hemoglobin level; $\mathrm{RBC}=$ red blood cell count; PLT = platelet count

Table 2 - Plasma chemistry values (mean $\pm \mathrm{SD})$ and range in foraging hawksbill turtles $(\mathrm{n}=47)$ nesting on the Mexican coast Campeche - 2014/ 2015

\begin{tabular}{ccc}
\hline Parameter & Mean \pm SD & Range \\
\hline CCL & $89,20 \pm 6,38$ & $75,50 \pm 100,00$ \\
CCW & $78,34 \pm 8,52$ & $39,00 \pm 93,50$ \\
Urea $(\mathrm{mg} / \mathrm{dL})$ & $26,03 \pm 14,57$ & $10,13 \pm 81,00$ \\
Glucose $(\mathrm{mg} / \mathrm{dL})$ & $101,19 \pm 30,86$ & $0,94 \pm 148,00$ \\
Creatinine $(\mathrm{mg} / \mathrm{dL})$ & $0,57 \pm 0,27$ & $0,11 \pm 1,26$ \\
Uric acid $(\mathrm{mg} / \mathrm{dL})$ & $1,06 \pm 0,69$ & $0,28 \pm 3,80$ \\
Triglyceride $(\mathrm{mg} / \mathrm{dL})$ & $470,80 \pm 214,13$ & $89,74 \pm 1228,00$ \\
Cholesterol $(\mathrm{mg} / \mathrm{dL})$ & $177,66 \pm 64,84$ & $37,07 \pm 326,00$
\end{tabular}

$\mathrm{CCL}=$ curved carapace length; $\mathrm{CCW}=$ curved carapace width

\section{Discussion}

Evaluating the health status and diagnosing diseases in hawksbill turtles based on blood samples from the monitoring of hematologic values and biochemical parameters could be useful for future conservation and rehabilitation projects and to prevent malformations in embryos and hatchlings. The general health of the turtles in this study was rated as good based on nest-building activity, energy level, and body condition, with all of these turtles able to successfully come ashore to nest.

Urea values ranged from 11 to $70 \mathrm{mg} / \mathrm{dL}$ (mean $35.25 \mathrm{mg} / \mathrm{dL} \pm 13.50$ ), the mean plasma urea values presented in studies with hawksbill turtles were $9.14 \mathrm{mg} / \mathrm{dL}$ ( \pm 1.29) (EHSANPOUR et al., 2015), and in this study the values analyzed were $26.03 \mathrm{mg} / \mathrm{dL}$ ( \pm 14.57).

Glucose concentrations in the hawksbill were similar to those reported for the nesting herbivorous green sea turtle, $96.1 \mathrm{mg} / \mathrm{dL}( \pm 21.5)$ (MCFADDEN et al., 2014) and like those reported for the other studies with hawksbill turtle, $104 \mathrm{mg} / \mathrm{dL}( \pm 30)$ (CALIENDO et al., 2010), and $106 \mathrm{mg} / \mathrm{dL}$ ( \pm 7.83) (EHSANPOUR et al., 2015), similar to the values of this study $10.19 \mathrm{mg} / \mathrm{dL}( \pm 30.86)$.

Normal values for serum creatinine are generally very low, less than $1 \mathrm{mg} / \mathrm{dL}$, and high values are expected in severe dehydration and renal diseases (CAMPBELL, 1996).
Caliendo et al. (2010) found an average of $1.4 \mathrm{mg} / \mathrm{dL}( \pm 404)$ of creatinine in the plasma of hawksbill turtles, and Ehsanpour et al. (2015) by an average $0.23 \mathrm{mg} / \mathrm{dL}( \pm 0.03)$, normal values of creatinine as obtained in this study. Creatinine concentration determination was also the subject of studies by Camacho et al. (2013), which presented a value lower than $0.1 \mathrm{mg} / \mathrm{dL}$, and Innis et al. (2008), which obtained the mean of $0.1 \mathrm{mg} / \mathrm{dL}( \pm 0.1)$, for the species L. kempii.

Uric acid is the end product of the primary catabolism of proteins, non-protein nitrogen, and purines in reptiles, and diet can influence uric acid levels, especially those rich in protein and urea, since carnivorous reptiles have higher uric acid blood levels (CAMPBELL, 1996). Some papers present values of this parameter for green turtles. McFadden et al. (2014), found an average of $0.9 \mathrm{mg} / \mathrm{dL}( \pm 0.5)$, as well as Caliendo et al. (2010) $1.7 \mathrm{mg} / \mathrm{dL}( \pm 0.4)$, in this study, close values were found for hawksbill turtle $1.06 \mathrm{mg} / \mathrm{dL}( \pm 0.69)$. However, in loggerhead sea turtles, that have a different feed, mean uric acid values were found that ranged between $0.3 \mathrm{mg} / \mathrm{dL}$ and $1.2 \mathrm{mg} / \mathrm{dL}$ (mean $0.62 \mathrm{mg} / \mathrm{dL} \pm 0.21$ ) (GOLDBERG et al., 2011).

Cholesterol and triglyceride values are often elevated during vitellogenesis (HAMANN et al., 2002). The 
mean plasma triglyceride values presented in studies with hawksbill turtle were $376.42 \mathrm{mg} / \mathrm{dL}( \pm 50.20)$ (EHSANPOUR et al., 2015), Those results were lower than those found in this study $470.80 \mathrm{mg} / \mathrm{dL}( \pm 214.13)$, while values obtained with loggerhead sea turtle were $977.34 \mathrm{mg} / \mathrm{dL}$ ( \pm 327 ) (CAMACHO et al., 2013).

According to Swimmer (2000), reptiles kept in captivity have higher levels of triglycerides, due to a high fat diet and insufficient exercise, or both. For the green sea turtle, McFadden et al. (2014), found an average of $164.9 \mathrm{mg} / \mathrm{dL}$ ( \pm 55 ) of total cholesterol in plasma samples, while, Ehsanpour et al. (2015), found an average of $158.58 \mathrm{mg} / \mathrm{dL}$ ( \pm 19.94$)$ in plasma samples for the hawksbill turtle, similar to the values found in the present study of $176.66 \mathrm{mg} / \mathrm{dL}( \pm 64.84)$.

The values reported in this study provide reference ranges of hematologic and biochemical parameters that may be useful for assessing and monitoring the health status of hawksbill turtles. Through comparisons among populations, detecting changes in health status among turtles, and associations between specific biochemical parameters, we can reduce and prevent disease and malformations in embryos and hatchlings, thus

\section{References}

AGUIRRE, A. A.; BALAZS, G. H. Blood biochemistry values of green turtles, Chelonia mydas, with and without fibropapillomatosis. Comparative Haematology International, v. 10, n. 3, p. 132-137, 2000. doi: 10.1007/ s005800070004.

AGUIRRE, A. A.; BALAZS, G. H.; SPRAKER, T. R.; GROSS, T. S. Adrenal and hematological responses to stress in juvenile green turtles (Chelonia mydas) with and without fibropapillomas. Physiological and Biochemical Zoology, v.68,n.5,p.831-854,1995.doi: 10.1086/physzool.68.5.30163934.

BOLTEN, A. B. Techniques for measuring sea turtles. In: ECKERT, K. L.; BJORNDAL, K. A.; ABREU-GROBOIS F. A.; DONNELY, $M$. Research and management techniques for the conservation of sea turtles. Washington: IUCN/ SSC Marine Turtle Specialist Group, 1999. p. 110-114.

BOLTEN, A. B.; BJORNDAL, K. A. Blood profiles for a wild population of green turtles (Chelonia mydas) in the southern Bahamas: size-specific and sex-specific strengthening marine turtle management conservation in the medium- and long-term.

The hematological values found varied in relation to other authors, even when working with the same species, but using a different methodology. This reinforces the need to establish specific hematological values for each population, taking into account also characteristics such as the size of the animals and the methodology used. The data presented here may be useful as a reference in the assessment of the health and disease susceptibility of hawksbill populations from the Mexican coast. In addition, this study might contribute to the rehabilitation of sick animals and their reintroduction into the wild.

\section{Acknowledgements}

The license (SGPA/DGVS/03974/14) to collect the blood samples of 47 turtles was provided by the Secretaria de Medio Ambiente y Recursos Naturales (Semarnat). The authors want to thank the turtle camp Grupo Ecologista Quelonios A.C. officials who aided in the fieldwork at Punta Xen. This work was supported by Coordination for the Improvement of Higher Education Personnel (Capes Brazil) (1201/2013-01).

relationships. Journal of Wildlife Diseases, v. 28, n. 3, p. 407-413, 1992. doi: 10.7589/0090-3558-28.3.407.

CALIENDO, V.; MCKINNEY, P.; ROBINSON, D.; BAVERSTOCK, W.; HYLAND, K. Plasma biochemistry and hematology values in juvenile hawksbill turtles (Eretmochelys imbricata) undergoing rehabilitation. Journal of Herpetological Medicine and Surgery, v. 20, n. 4, p. 117-121, 2010.

CAMACHO, M.; LUZARDO, O. P.; BOADA, L. D.; LÓPEZ JURADO, L. F.; MEDINA, M.; ZUMBADO, M.; ORÓS, J. Potential adverse health effects of persistent organic pollutants on sea turtles: evidences from a cross-sectional study on Cape Verde loggerhead sea turtles. Science of the Total Environment, v. 458-460, p. 283-289, 2013. doi: 10.1016/j.scitotenv.2013.04.043.

CAMPBELL, T. Sea turtle rehabilitation. In: MADER, D. (Ed.). Reptile medicine and surgery. Philadelphia: W. B. Saunders, 1996. p. 427-436. 
CHRISTOPHER, M. M.; BERRY, K. H.; WALLIS, I. R.; NAGY, K. A.; HENEN, B. T.; PETERSON, C. C. Reference intervals and physiologic alterations in hematologic and biochemical values of free-ranging desert tortoises in the Mojave Desert. Journal of Wildlife Diseases, v. 35, n. 2, p. 212-238, 1999. doi: 10.7589/0090-3558-35.2.212.

EHSANPOUR, M.; AHMADI, M. R.; BAHRI, A. H.; AFKHAMI, M.; REICH, K. J. Plasma biochemistry values in wild female hawksbill turtles (Eretmochelys imbricata), during nesting and foraging seasons in Qeshm Island, Persian Gulf. Comparative Clinical Pathology, v. 24, n. 3, p. 561-566, 2015. doi: 10.1007/s00580-014-1945-3.

ESCANERO, F. G. A.; VIGILANTE, S.; GÓMEZ G. Informe anual del programa de protección y estudio de las tortugas marinas en Isla Aguada-Sabancuy, Campeche, Temporada 1990. In: FRAZIER, J.; VÁZQUEZ, R.; GALICIA, E.; DURÁN, R.; CAPURRO, L. (Eds.). Memorias del IV Taller Regional sobre Programas de Conservación de Tortugas Marinas en la Península de Yucatán, 11-13 de Marzo, 1991. Yucatán: Universidade Autónoma de Yucatán, 1993. p. 77-90.

GOLDBERG, D. W.; WANDERLINDE, J.; FREIRE, I. M. A.; SILVA, L. C. P.; ALMOSNY, N. R. P. Serum biochemistry profile determination for wild loggerhead sea turtles nesting in Campos dos Goytacazes, Rio de Janeiro, Brazil. Ciência Rural, v. 41, n. 1, p. 143-148, 2011. doi: 10.1590/S0103-84782011000100023.

GUZMÁN, V. H.; GARCÍA, P. A. Informe técnico 2009 del Programa de Conservación de Tortugas Marinas en Laguna de Términos. Campeche: APFFLT/RPCyGM/ CONANP, 2010. 67 p.

HAMANN, M.; LIMPUS, C. J.; OWENS, D. W. Reproductive cycles of males and females. In: LUTZ, P. L.; MUSICK, J. A.; WYNEKEN, J. (Eds.). The biology of sea turtles. Boca Raton: CRC Press, 2002. p. 135-162. v. 2.

INNIS, C.; TLUSTY, M.; PERKINS, C.; HOLLADAY, S.; MERIGO, C.; WEBER III, S. E. Trace metal and organochlorine pesticide concentrations in cold-stunned juvenile kemp's ridley turtles (Lepidochelys kempii) from Cape Cod, Massachusetts. Chelonian Conservation and Biology, v. 7, n. 2, p. 230-239, 2008. doi: 10.2744/CCB0707.1.
INTERNATIONAL UNION FOR CONSERVATION OF NATURE (IUCN). A global strategy for the conservation of marine turtles. Cambridge: IUCN, 1995. 25 p.

IUCN RED LIST OF THREATENED SPECIES. Cambridge: IUCN, 2016.

LUTCAVAGE, M. E.; PLOTKIN, P.; WITHERINGTON, B.; LUTZ. P. L. Human impacts on sea turtle survival. In: LUTZ, P. L.; MUSICK, J. A.; WYNEKEN, J. (Eds.). The biology of sea turtles. Boca Raton: CRC Press, 1997. p. 387-409.

LUTZ, P. L.; DUNBAR-COOPER, A. Variations in the blood chemistry of the loggerhead sea turtle, Caretta caretta. Fish Bull, v. 85, n. 1, p. 37-44, 1987.

MCFADDEN, K. W.; GÓMEZ, A.; STERLING, E. J.; NARO-MACIEL, E. Potential impacts of historical disturbance on green turtle health in the unique \& protected marine ecosystem of Palmyra Atoll (Central Pacific). Marine Pollution Bulletin, v. 89, n. 1-2, p. 160167, 2014. doi: 10.1016/j.marpolbul.2014.10.012.

MÉXICO. Secretaria del Medio Ambiente y Recursos Naturales. Norma Oficial Mexicana NOM-162Semarnat-2012. Que establece las especificaciones para la protección, recuperación y manejo de las poblaciones de las tortugas marinas en su hábitat de anidación. Diario Oficial de la Federación, Cuidad de México, 1 feb. 2013.

OWENS, D. W.; RUIZ, G. J. New methods of obtaining blood and cerebrospinal fluid from marine turtles. Herpetologica, v. 36, n. 1, p. 17-20, 1980.

PIRES, T. T.; ROSTAN, G.; BITTENCOURT, T. C. C.; GUIMARÃES, J. E. Hemograma e bioquímica sérica de tartarugas cabeçudas (Caretta caretta) de vida livre e mantidas em cativeiro, no litoral norte da Bahia. Brazilian Journal of Veterinary Research and Animal Science, v. 46, n. 1, 2009. doi: 10.11606/issn.1678-4456. bjvras.2009.26744.

ROUSSELET, E.; LEVIN, M.; GEBHARD, E.; HIGGINS, B. M.; DEGUISE, S.; GODARD-CODDING, C. A. J. Evaluation of immune functions in captive immature 
loggerhead sea turtles (Caretta caretta). Veterinary Immunology and Immunopathology, v. 156, n. 1-2, p. 43-53, 2013. doi: 10.1016/j.vetimm.2013.09.004.

SWIMMER, J. Y. Biochemical responses to fibropapilloma and captivity in the green turtle. Journal of Wildlife Diseases, v. 36, n. 1, p. 102-110, 2000. doi: 10.7589/00903558-36.1.102.
THE R FOUNDATION. R: a language and environment for statistical computing. R Foundation, Vienna, 2015. Available from: <https://goo.gl/A1hZwh>. Viewed: 29 May 2018.

WOOD, F. E.; EBANKS, G. K. Blood cytology and hematology of the green sea turtle, Chelonia mydas. Herpetologica, v. 40, n. 3, p. 331-336, 1984. 